\title{
Paroxysmal dystonia and neuromyelitis optica
}

\section{Distonia paroxística e neuromielite óptica}

Felipe R. Schmidt', Flavio Henrique R. Costa ${ }^{1}$, Fernanda M.L.C. Silva1, Henryk Maultasch'1, Ana Lucia Rosso', Denise H. Nicaretta², James P. de Mattos', Sergio A.P. Novis',2, Soniza V. Alves-Leon'

\begin{abstract}
Paroxysmal dyskinesias (PD) are thought to be rare movement disorders. The overwhelming majority of reported cases are primary. Secondary PD has seen reported to occur in some conditions, mainly in multiple sclerosis and head trauma. The anatomic origin of the lesion is also rarely seen at the spinal cord. Our objective was to describe four patients with paroxysmal dystonia secondary to spinal lesions during the recovering phase of a neuromyelitis optica (NMO) bout. In the reviewed literature, we do not find any report of PD related to NMO.
\end{abstract}

Key words: paroxysmal dyskinesias, paroxysmal dystonia, neuromyelitis optica.

\section{RESUMO}

Discinesias paroxísticas (DP) são distúrbios do movimento raros. A maioria dos casos relatados é de origem primária. DP secundárias têm sido relatadas em algumas condições, principalmente na esclerose múltipla e no trauma craniano. A origem anatômica da lesão também é raramente observada na medula. 0 objetivo deste trabalho foi descrever quatro pacientes com distonia paroxística secundária a lesões medulares, ocorrida durante a fase de recuperação do surto de neuromielite óptica (NMO). Na literatura consultada, não encontramos qualquer relato de DP secundárias à NMO.

Palavras-Chave: discinesias paroxísticas, distonia paroxística, neuromielite óptica.

Neuromyelitis optica (NMO) is a severe autoimmune disease of the central nervous system whose clinical spectrum ranges from unilateral isolated optic neuritis to extensive myelitis with bilateral optic neuritis. Dystonia is characterized by sustained muscle contractions, frequently causing twisting and repetitive movements, or abnormal postures. It can be continual or paroxysmal and focal, segmental, multifocal, generalized or hemidystonic according to the bodily distribution. Concerning its etiology, secondary dystonia can originate from lesions in the central (basal ganglia and upper cervical cord) or peripheral nervous system. Our objective was to report four patients with paroxysmal dystonia related to NMO.

\section{METHODS}

Four non-consecutive in-patients with NMO were admitted in our Hospital to treat a relapse between 2008-2009. All patients fulfill the Weinshenker et al. ${ }^{1}$ diagnostic criteria. The dystonia was characterized according to Ad Hoc Committee of the Scientific Advisory Board of the Dystonia Medical Research Foundation, $1984^{2}$. This study was approved by the local ethics committee.

\section{RESULTS}

Four female patients were admitted with an acute attack of cervical or cervico-dorsal myelitis. The clinical details of each patient are seen in Table.

\section{Case histories}

Patient 1: A 65-year-old woman had a subacute tetraparesis and left visual loss in the 1970's. She developed many bouts and remissions with progressive atrophy of the distal right arm. In November 2007, during a new bout of subacute tetraparesis, a cervical magnetic ressonance imaging (MRI) revealed an extensive T2 and Flair hyperintense lesion with contrast enhancement with a hypointense lesion suggestive of acute myelitis and also a syrinx. Brain MRI was normal. Cerebrospinal fluid (CSF) was not performed due to her unstable clinical condition. She was then treated with plasmapheresis, IV metilprednisolone and immunoglobulin with mild motor improvement, being able to sit up. During the recovery, she presented with painful kinesigenic paroxysmal dystonic movements in the four limbs, mostly in the upper limbs. Carbamazepine $600 \mathrm{mg} /$ day abolished the abnormal movements.

\footnotetext{
1 Serviço de Neurologia Professor Sergio Novis, Hospital Universitário Clementino Fraga Filho, Universidade Federal do Rio de Janeiro (UFRJ), Rio de Janeiro RJ, Brazil; ${ }^{2}$ Vigésima Quinta Enfermaria da Santa Casa de Misericórdia do Rio de Janeiro, Rio de Janeiro RJ, Brazil. 
Table. Patients details.

\begin{tabular}{lcclll} 
Patients & $\begin{array}{c}\text { Age } \\
\text { (years) }\end{array}$ & $\begin{array}{c}\text { Disease } \\
\text { duration (years) }\end{array}$ & \multicolumn{1}{c}{ Neurological examination } & Dystonia distribution and type of PD & $\begin{array}{c}\text { MRI (sites of the } \\
\text { acute lesions) }\end{array}$ \\
\hline 1 & 65 & 37 & tetraparesis, bilateral amaurosis & four limbs kinesigenic & cervical \\
2 & 35 & 8 & paraparesis, bilateral amaurosis & left upper limb, lower limbs kinesigenic & cervical \\
3 & 51 & 1 & paraplegia, left optic neuritis & lower limbs, non-kinesigenic & thoracic \\
4 & 34 & 8 & paraparesis, bilateral amaurosis & right limbs kinesigenic & cervical and thoracic \\
\hline
\end{tabular}

PD: paroxysmal dystonia; MRI: magnetic ressonance imaging.

Patient 2: A 35-year-old woman had bilateral visual loss and paraparesis in 1999. She had several attacks and incomplete remissions. In March 2007, she had an acute cervical myelitis with palsy of the lower limbs and the left upper limb. CSF revealed 8 cells ( $92 \%$ lymphocytes), protein $=49 \mathrm{mg} \%$, glucose $=63 \mathrm{mg} / \mathrm{dL}, \operatorname{IgG}$ index=13.2 with oligoclonal bands positive. Cervical and dorsal MRI showed T2 hypersignal lesion in both. Plasmapheresis and IV metilpredinisolone were introduced, and she was able to walk without assistance after a few weeks. During treatment, she presented with kinesigenic paroxysmal dystonia in both legs and in the left arm. She had a marked improvement of the dystonia after carbamazepine $600 \mathrm{mg} /$ day.

Patient 3: A 51-year-old woman presented with left optic neuritis in December 2006. She developed acute paresthesis in the lower limbs, back pain and sensitive level in D12 in March 2007. The symptoms worsened in a few weeks and she became paraplegic, with urinary retention, and the sensitive level was in D8. Dorsal MRI showed a hyperintense T2 lesion that extended from D2 to D9 with no contrast enhancement. Brain MRI did not depict any lesions suggestive of multiple sclerosis. CSF exam showed 26 cells (80\% lymphocytes), protein $=108 \mathrm{mg} / \mathrm{dL}$, glucose $=75 \mathrm{mg} \%$, IgG index=0.7 (normal $\leq 0.85$ ) and failure to demonstrate oligoclonal bands. She was treated with plasmapheresis, IV metilprednisolone and immunoglobulin with marked motor improvement, being able to walk without assistance. During the recovery time, nonkinesigenic paroxysmal dystonia of the lower limbs was noticed and then disappeared after the introduction of carbamazepine $900 \mathrm{mg} /$ day.

Patient 4: A 34-year-old woman presented with bilateral amaurosis in 1998 and she developed numerous attacks of cervical myelitis. A new bout of cervical myelitis resulting in tetraplegia and dyspnea, bilateral amaurosis and marked proprioceptive impairment occured in June 2007. Cervical spinal MRI showed a large hyperintense T1, T2 and Flair lesion. CSF exam revealed 5 cells (100\% lymphocytes), protein=35 mg/dL and glucose=51 mg\%. IV metilprednisolone and immunoglobulin were introduced with respiratory distress and motor function improvement, and she was then able to walk with assistance. During the recovery time, kynesigenic paroxysmal right hemidystonia was seen and then abolished after the introduction of carbamazepine $600 \mathrm{mg} /$ day.

\section{DISCUSSION}

In 1940, Mount and Reback introduced the concept of paroxysmal type movement disorders while describing attacks of tonic spasms and choreic and athetotic movements in a 23-year-old patient who had had both large (up to 2 hours) and small ( from 5 to 10 minutes) "spells" since infancy ${ }^{3}$. Their work became the seminal paper in the field of paroxysmal dyskinesia $(\mathrm{PD})^{2}$.

The paroxysmal dyskinesias are classified in six types: Kinesigenic (PKD), Non-kinesigenic (PNKD), Exertional (PED), Hypnogenic (PHD), Benign in Infancy and Childhood (PBDIC) and Epilepsy (PDE) ${ }^{2}$. Since our patients presented with the first two types, we will emphasize only PKD and PNKD.

In the first one, the duration ranges from seconds to five minutes, and the etiology can be primary (familial or sporadic) or secondary. In the second, the duration ranges from two minutes to four hours, and the etiology can be primary (familial or sporadic), secondary, alternating hemiplegia of childhood or psychogenic ${ }^{2}$. The overwhelming majority of reported cases in the literature of both types are primary. Although not reported as often, secondary type is probably more common and has been reported to occur in patients with multiple sclerosis, progressive supranuclear palsy, hyperglycemia, spinal cord lesion, subacute sclerosing panencephalitis, Huntington's disease, HIV infection, medulla oblongata lesions ${ }^{2}$. Paroxysmal dystonia, also called tonic spasm, is an uncommon movement disorder in association with multiple sclerosis (MS) ${ }^{2,4}$. These abnormal involuntary movements can occur at the initial presentation or at relapses of $\mathrm{MS}^{5,6}$ and are known to disappear within a few weeks spontaneously or after steroid treatment. It is believed that tonic spasms occur at any level in a motor path. Otherwise, there is no report in the reviewed literature of PD related to NMO.

PKD associated with pure spinal cord lesions is $\operatorname{rare}^{7,8}$. Cosentino et al. $^{7}$ reported a case of PKD associated with an intraspinal lesion. The attacks were precipitated by movement and also by deep nociceptive stimulus. Although the anatomical basis of secondary PKD is variable, the authors believe that a deep sensory system plays an important role in the pathogenesis of the attacks. Brown et al. ${ }^{9}$ described a patient with paroxysmal truncal flexion spasms of spinal origin, presumably involving the propriospinal pathways. All of our 
patients had cervical spinal lesions without brainstem, thalamic or cerebral lesions. All of them had severe transverse myelitis with involvement of the propriospinal pathways.

Pathophysiologically, some authors suggest that PD are channelopathies ${ }^{2}$ and, since NMO is considered a novel channelopathy (presence of antibodies to water channel aquaporin-4), it is no surprise to find these abnormal movements associated with NMO. It is difficult to explain why these movements occurred at the time of recovery rather than during the acute phase. However, we speculate that the severe damage to the spinal cord did not allow the clinical expression of PD in the acute phase of the NMO. Therefore, we believe that local biochemical imbalance during the period of recovery could have prompted the disinhibition of spinal interneurons and then the onset of PD.

In conclusion, to the best of our knowledge, this is the first description in the literature of paroxysmal dystonia in the course of NMO.

\section{ACKNOWLEDGEMENTS}

We thank Mr. Dominic Barter for his kind assistance in reviewing the manuscript.

\section{References}

1. Weinshenker BG, Wingerchuk DM. Neuromyelitis optica: clinical syndrome and the NMO-IgG autoantibody marker. Curr Top Microbiol Immunol 2008;318:343-356.

2. Fahn S, Jankovic J. The paroxysmal dyskinesias. In: principles and practice of movement disorders. Fahn S, Jankovic J (eds). Philadelphia: Elsevier; 2007: 554-575.

3. Mount LA, Reback S. Familial paroxysmal choreoathetosis. Arch Neurol Psychiat 1940;44:841-847.

4. Waubant E, Alizé P, Tourbah A, Agid Y. Paroxysmal dystonia (tonic spasm) in multiple sclerosis. Neurology 2001;57:2320-2321.

5. Berger JR, Sheremata WA, Melamed E. Paroxysmal dystonia as the initial manifestation of multiple sclerosis. Arch Neurol 1984;41:747-750.

6. Maimone D, Reder A, Finocchiaro F, Recupero E. Internal capsule plaque and tonic spasms in multiple sclerosis. Arch Neurol 1991;48:427-429.

7. Cosentino C, Torres L, Flores M, Cuba JM. Paroxysmal kinesigenic dystonia and spinal cord lesion. Mov Disord 1996;11:453-455.

8. Previdi P, Buzzi P. Paroxysmal dystonia due to a lesion of the cervical cord: case report. Ital J Neurol Sci 1992;13:521-523.

9. Brown P, Thompson PD, Rothwell JC, Day BL, Marsden CD. Paroxysmal axial spasms of spinal origin. Mov Disord 1991;6:43-48. 